\title{
Jakość życia i poczucie sukcesu u absolwentów szkoły polskiej na Lotwie. Studium zbiorowego przypadku
}

Streszczenie: Toruńskie środowisko naukowe przez 25 lat obserwuje (na początku aktywnie uczestnicząc w tym procesie) działanie Polaków na Łotwie, mające na celu odbudowę szkoły dla mniejszości polskiej. Prowadzenie badań longitudinalnych pozwala nam uchwycić dynamikę procesu transmisji kultury, tradycji i języka polskiego, wskazać rolę podmiotów szkoły mających kluczowe znaczenie dla kształtowania się poczucia tożsamości narodowej pokolenia młodych Polaków urodzonych i mieszkających na Łotwie, korzystających z szansy edukacji w języku polskim i łotewskim. Towarzyszyliśmy uczniom przez okres edukacji szkolnej, będąc przy nich w momentach ważnych, tj. rozpoczęcia oraz ukończenia podstawowej szkoły polskiej i przejścia do szkoły średniej łotewskiej czy rosyjskiej. Niniejszy projekt badawczy stanowi kontynuację poprzednich eksploracji. Tym razem uwaga nasza skupiona jest na absolwentach szkoły (pierwsze cztery roczniki) - dzisiaj młodych trzydziestolatkach. Problem główny projektowanych badań zawiera się w pytaniach: Jaka jest jakość życia i poczucie osobistego sukcesu młodych absolwentów szkoły polskiej w Rydze i w jaki sposób są one różnicowane cechami usytuowania socjodemograficznego, aktualną sytuacją życiową i zawodową, uwarunkowane kontekstem społeczno-kulturowym, w jakim funkcjonują jako ludzie dorośli? Proponujemy ujęcie jakości życia i osiągniętego statusu społecznego absolwentów w formie przedstawienia trajektorii ich życia.

Słowa kluczowe: poczucie tożsamości, kapitał kulturowy i społeczny, jakość życia, poczucie sukcesu, szkolnictwo polskie na obczyźnie, trajektorie życia

Łotwa jest specyficznym przykładem pogranicza kulturowego. Specyfika ta wiąże się przede wszystkim z występującą różnorodnością kulturowo-etniczną, bowiem są to tereny wzajemnego styku kultury łotewskiej z kulturami narodów: polskiego, białoruskiego, rosyjskiego i ukraińskiego. Problem tamtejszego pogranicza kulturowego jest złożony, wynikający z faktu przeszło 
pięćdziesięcioletniej polityki wynaradawiania ludności kraju. Próbowano stworzyć jednolite pod względem gospodarczym, politycznym, kulturowym i językowym państwo, konsekwentnie pozbawiając zamieszkałe tam nacje własnej historii, języka, kultury i religii. Polityka sowietyzacji i indoktrynacja komunistyczna miały doprowadzić do wykształcenia nowej, sowieckiej tożsamości - „homo sovieticus” (określenie A. Zinowiewa). Człowiek ten miał być bezwolnym narzędziem w rękach władzy radzieckiej i mógł w zamian za bezwzględne posłuszeństwo i podporządkowanie ideologii komunistycznej konsumować jego dobra (mieszkanie, praca, przywileje).

Po rozpadzie ZSRR w 1989 roku ludność zamieszkująca Łotwę przeżyła bardzo silny kryzys tożsamości. Wielu stawiało sobie pytanie „kim naprawdę jestem?” czy też „jakiej jestem narodowości?”. Problem narodowej samoidentyfikacji stał się problemem kluczowym w momencie budzenia się świadomości narodowej i budowania własnych struktur państwowych na Łotwie. Ustawa o obywatelstwie z 1990 roku podnosiła sprawę narodową, ściśle określając, jakie warunki w kwestii języka czy narodowości należy spełniać, starając się o pracę lub chcąc przynależeć do określonych partii politycznych. Tak radykalna zmiana sytuacji społeczno-politycznej postawiła przed ludnością rosyjskojęzyczną (w tym także przed większą częścią zamieszkujących tam Polaków) bardzo wysokie wymagania, którym niełatwo było sprostać. Mieszkańcy rosyjskojęzyczni to byli w większości bezpaństwowcy, bez obywatelstwa i prawa do ziemi, czynnego prawa wyborczego. Pewne ograniczenia oraz negatywne nastawienie Łotyszy wobec tej grupy społecznej zrodziło w nich poczucie zagrożenia, obawy o marginalne funkcjonowanie w przyszłym państwie łotewskim.

Złożoność problematyki pogranicza kultur na Łotwie związana jest ze współistnieniem (obok siebie/razem) różnych narodowości, a w przypadku kształtowania tożsamości dzieci uczęszczających do szkoły polskiej dodatkowo zdeterminowana stanem i jakością edukacji pozwalającej na zakotwiczenie w dwu kulturach: polskiej i łotewskiej. Proces przekazu doświadczenia zbiorowego, niezależnie od tego, jaki reprezentują stopień złożoności, dokonuje się zawsze w obrębie określonych grup społecznych. Różne grupy danej zbiorowości odgrywają niejednakową rolę jako ośrodki przekazu i asymilacji kultury dla oznaczenia zbiorowości (grupy, organizacji), w jakiej zachodzi przekaz kulturowy i tym samym socjalizacja jednostki ${ }^{1}$.

1 R. Schulz: Szkoła - instytucja - system - rozwój. Toruń 1992, „Edytor”, s. 35. 
Socjalizacja jest to proces, w toku którego jednostka przyswaja sobie zasób kulturowy poszczególnych grup społecznych, wchodzących w skład tego społeczeństwa. Jest to podstawowa forma uczenia się kultury (wzorów myślenia, wartościowania i zachowania). Przebiega nie tylko w zbiorowościach naturalnych jak np. w rodzinie, występuje też tam, gdzie jednostka, stając się członkiem danej społeczności, musi nauczyć się swej roli, odpowiadającej jej zmienionej pozycji. Niemniej to właśnie rodzina uchodzi za klasyczny ośrodek uspołecznienia. Stanowi pierwszą i podstawową instytucję opieki, wychowania i kształcenia jednostki. Wielu badaczy podkreśla, że rodzina może być nie tylko instytucją wychowania naturalnego i spontanicznego, lecz także intencjonalnego ${ }^{2}$. Istnieje ona dla utrzymania, rozwijania i przekazywania dziedzictwa kulturalnego zbiorowości społecznej oraz dla socjalizacji i wychowania młodego pokolenia.

Utworzenie szkoły polskiej na Łotwie w roku 1989 było spontaniczną inicjatywą głównie pokolenia dziadków, którzy poddając się procesom asymilacyjnym w okresie po drugiej wojnie światowej, pozwolili zrusyfikować własne dzieci, a tożsamość polską odbudowują w swoich wnukach. Pokolenie dziadków, nie posiadając dostatecznych kompetencji kulturowych, nie znając dobrze języka przodków, nie kultywując już tradycji polskich, powołało do życia placówkę, która mogła wesprzeć ich w procesie socjalizacji pokolenia wnuków. Często to wnuki stają się sensem życia dziadków, ich dumą, a dziadkowie, wiążąc z nimi wiele oczekiwań, pragną, aby w przyszłości osiągnęły to, czego im nie udało się w życiu osiągnąć. Potrzeba przekazu kultury polskiej przez dziadków najmłodszemu pokoleniu „wypływa z głębi ich serca” i wydaje się odczuwana przez nich jako powinność, a nawet obowiązek. Owa potrzeba stanowi silne pragnienie i ostatnią wolę dziadków. Jest to swoisty testament najstarszego pokolenia ${ }^{3}$.

Pokolenie dziadków uczniów szkoły polskiej na Łotwie od początku wykazywało niezwykłą aktywność w tworzeniu szkoły. Mając poczucie, iż im samym brak jest wiedzy o tradycji, kulturze i przeszłości własnego narodu,

2 E. Trempała: Instytucje i placówki wychowania równolegtego. W: T. Pilch, B. Smolińska-Theiss (red.): Pedagogika społeczna - poszukiwania i rozstrzygnięcia. Wrocław - Warszawa 1984, Zakład Narodowy im. Ossolińskich, s. 155.

3 Określenie użyte przez M. M. Urlińską - testament rozumiany jako wola dziadków ma tutaj zabarwienie nieco metaforyczne. Spadkodawcą są dziadkowie, a majątek ich stanowią nie dobra materialne, ale duchowość i cała tkwiąca w nich polskość, którą przekazują swym spadkobiercom - wnukom - jako dziedzictwo kulturowe. 
a także językowych kompetencji (bowiem ich polskość często jest już tylko „podskórna”), rzucili się w wir tworzenia instytucji edukacyjnej wspierającej proces socjalizacji w duchu polskości. Tworzyli szkołę, w której ktoś odpowiedzialny i profesjonalnie przygotowany do roli transmitującego kulturę polską (nauczyciel z Polski) stanąłby wespół z nimi, by przekazać informacje, poglądy, wierzenia, którym przypisuje się wartość poznawczą i/lub praktyczną. Wychodząc z konspiracyjnego kultywowania polskości w czasach sowietyzacji, pozwolili, by to, co polskie w ich życiu, ujrzało światło dzienne, mogło być wykorzystane w procesie szkolnej edukacji. Wyczuwało się wyjątkowość sytuacji i jakby nowe życie, które promieniowało od tych, którzy przez lata sprawiali wrażenie „uśpionych”.

Z dotychczasowych badań w szkole polskiej w Rydze wynika, że placówka ta stała się elementem wspierającym dziadków w procesie socjalizacji w duchu polskości ich wnuków. Poprzez szkołę polską dziadkowie chcieli polonizować wnuków, a w praktyce okazało się, że ci repolonizują swoich rodziców (pętla socjalizacyjna) ${ }^{4}$. To dziadkowie chcieli stworzyć podstawy kształtowania się poczucia osadzenia w przeszłości rodziny, sprzyjając tym samym rozwojowi tożsamości indywidualnej ${ }^{5}$. Poprzez kształtowanie się u wnuków poczucia zakorzenienia narodowego wpływali w ten sposób na rozwój ich tożsamości narodowej.

Właśnie w takiej sytuacji na przełomie lat 80. i 90. ubiegłego wieku znalazło się pokolenie trzydziestolatków - rodziców, przed którymi stał problem wyboru szkoły podstawowej dla swoich dzieci. Chcieli dla nich innej, lepszej przyszłości, a wiedzieli dobrze, jaką w tej społecznie i politycznie skomplikowanej sytuacji istotną rolę ma do odegrania szkoła. To ona mogła pomóc nabyć młodym ludziom kompetencje do funkcjonowania w nowych realiach niepodległej Łotwy, na warunkach stawianych rosyjskojęzycznej mniejszości przez większość łotewską. Trzeba pamiętać, że dwie trzecie wszystkich Po-

4. Kultura, która przekazywana jest dzieciom przez starsze pokolenie, M. Mead nazywa kulturą postfiguratywną. Odróżnia ją od kultur kofiguratywnych, w których ludzie uczą się od swych rówieśników i kultur prefiguratywnych, w których starsi uczą się od swych dzieci i wnuków. W okresie, gdy dzieci są w wieku przedszkolnym i szkolnym, aż do okresu dojrzewania przejmują treści socjalizacyjne głównie od swych rodziców i dziadków, a grupy rówieśnicze i instytucje kształcące dopiero stopniowo zaczynają przejmować rolę inspirującą. Jest to jeszcze okres dominacji kultury postfiguratywnej. Por.: M. Mead: Kultura i tożsamość. Warszawa 1978, PWN.

5 M. Tyszkowa: Relacje dorastających wnuków z dziadkami i babciami. „Problemy Rodziny" 1992, nr 1. 
laków mieszkających na Łotwie to ludność napływowa z terenów Białorusi, Ukrainy czy Rosji. Z tej właśnie grupy rekrutowali się rodzice dzieci szkoły polskiej ${ }^{6}$. Projektując przyszłość swoich dzieci, chcieli dla nich innej - niż rosyjska - alternatywy edukacyjnej, innej - niż własna - perspektywy życiowej. Byli przekonani o nieodwracalności ostatnich przemian ustrojowych i społecznych na Łotwie. Decydując o przyszłości dzieci, szukali najlepszej dla nich drogi do awansu społecznego czy drogi do kariery zawodowej i życiowej. A taką mogła zapewnić jedynie dobra szkoła.

Nasze dotychczasowe badania potwierdzają, że była to główna przyczyna wyboru przez rodziców szkoły polskiej jako komplementarnej formy edukacyjnej dla swoich dzieci. Rodzice mówili o swoich oczekiwaniach wobec szkoły polskiej. Prawie wszystkie wypowiedzi potwierdzały przekonanie, że oddanie dzieci pod opiekę tej placówki zwiększy ich szanse życiowe. Szkoła polska na Łotwie w swoim zamyśle miała być szkołą, w której edukacja pozwalałaby dzieciom polskim mieszkającym na Łotwie zakotwiczyć w dwu kulturach: polskiej i łotewskiej. Tok nauczania prowadzony równolegle w językach państwowym łotewskim i narodowym polskim umożliwiał identyfikację z kilkoma kulturami, poznanie krajów, języków, tradycji, poszerzenie wiedzy o ludziach, doświadczenie ich mentalności. Dziecko, zdobywając wiedzę w kilku językach, ma możliwość zwielokrotnienia kompetencji kulturowych i językowych, tym samym zwiększa się pulę ofert dla tworzącej się tożsamości jednostkowej i społecznej.

Toruńskie środowisko naukowe przez 25 lat obserwuje (na początku aktywnie uczestnicząc w tym procesie) działanie Polaków na Łotwie, mające na celu odbudowę szkoły dla mniejszości polskiej. Prowadzenie badań longitudinalnych pozwala nam uchwycić dynamikę procesu transmisji kultury, tradycji i języka polskiego, wskazać rolę podmiotów szkoły mających kluczowe znaczenie dla kształtowania się poczucia tożsamości narodowej (aspekt indywidualny i społeczny) pokolenia młodych Polaków urodzonych i mieszkających na Łotwie, korzystających z szansy edukacji w języku polskim i łotewskim. Przez wiele lat prowadzenia badań w działaniu w szkole polskiej w Rydze przyglądaliśmy się sytuacji społeczno-politycznej na Łotwie, w latach odbudowy państwowej struktury po latach panowania władzy radzieckiej i procesu rusyfikacji ludności zamieszkującej te tereny. Analizowa-

6 Sami czuli się pokoleniem przegranym, odciętym od tradycji, korzeni, historii przodków. Mieli za sobą swoje własne ścieżki edukacyjne, a byli to głównie absolwenci rosyjskich szkół. Ich rodzicom w czasach sowieckich te właśnie szkoły wydawały się atrakcyjne, bo w tamtych latach gwarantowały sukces i karierę młodego pokolenia. 
liśmy rolę instytucji edukujących, przygotowujących młodych ludzi do życia w tych konkretnych realiach (szukając uzasadnień dzisiejszych rozwiązań, sięgano do wątków historycznych) ${ }^{7}$.

Tok nauczania prowadzony w szkole polskiej równolegle w językach państwowym łotewskim i narodowym polskim umożliwiał identyfikację z kilkoma kulturami, poznanie krajów, języków, tradycji, poszerzenie wiedzy o ludziach, doświadczenie ich mentalności. Dziecko, zdobywając wiedzę w kilku językach, ma możliwość zwielokrotnienia kompetencji kulturowych i językowych, tym samym zwiększa się pulę ofert dla tworzącej się tożsamości jednostkowej i społecznej. Interesujące było uzyskanie odpowiedzi na pytanie, czy szkoła polska funkcjonująca w proponowanym kształcie (dwukulturowa, dwujęzyczna, integracyjna) może istotnie ułatwić dzieciom awans kulturowy i cywilizacyjny w pełnej uwikłań przestrzeni wielokulturowego pogranicza. Zastanawiano się wówczas nad tym, co można zrobić, aby zarówno oferta edukacyjna, jak i efekt jej działania były bogate kulturowo i życiodajne, pozwalały wydobyć potencjał tkwiący w młodych ludziach (upodmiotowienie ich), umożliwiały przekraczanie własnych ograniczeń.

Od początku stawialiśmy pytania, dlaczego rodzice wybrali właśnie tę szkołę, jakie motywy złożyły się na ich decyzję, czy rodzice przy wyborze kierowali się przede wszystkim swoją przynależnością narodową, czy też inne czynniki odegrały bardziej istotną rolę? Przyglądaliśmy się procesowi odbudowy szkoły w Rydze, istotna była wtedy dla nas informacja o tym, komu szkoła jest potrzebna, dla kogo i dlaczego jest szansą, jakie były motywy podjęcia decyzji przez rodziców (dziadków), czy przy wyborze kierowali się przede wszystkim swoją przynależnością narodową, czy też inne czynniki odegrały bardziej istotną rolę. Prowadząc badanie w działaniu w szkole polskiej w Rydze, stwierdziliśmy, że placówka ta stwarzała możliwość integracji różnych symboli kulturowych (polskich, łotewskich, rosyjskich), zwiększając jednostce szanse wyboru pozytywnej tożsamości, pozwoliło to (w sensie kulturowym) być Polakiem, a jednocześnie lojalnym i pełnoprawnym obywatelem łotewskim. Z naszych dotychczasowych analiz wynika, że szkoła polska staje się miejscem spotkań i wzajemnych kontaktów Polaków mieszkających na Łotwie oraz ich związków z krajem przodków. Wyjazdy do Polski organizowane przez szkołę to dla wielu rodziców jedyna możliwość kontaktu z Macierzą, kontakt z nauczycielem delegowanym do pracy z Polski staje się elementem kluczowym dla nabywania

7 M. M. Urlińska: Szkoła polska na obczyźnie wobec dylematów tożsamościowych. Toruń 2007, UMK. 
przez dzieci (ale także rodziców i dziadków) kompetencji kulturowych w zakresie wiedzy o Polsce, znajomości języka, tradycji i kultury polskiej.

Towarzysząc dzieciom w ich szkolnej edukacji, staraliśmy się więc odpowiedzieć na pytania: czy w rzeczywistości szkoła polska w Rydze pełni założoną pierwotnie funkcję integrującą elementy polskie, rosyjskie i łotewskie, czy wspiera proces adaptacji do zmian w społeczeństwie łotewskim, sprzyja wychodzeniu z funkcjonowania na podwójnym marginesie społeczeństwa dotychczas rusyfikowanego, czy w przyszłości sprosta nadziejom w niej pokładanym przez rodziców i ich dzieci? Prowadziliśmy więc badawczo indywidualne biografie przez okres edukacji szkolnej, będąc przy dziecku w momentach dla niego ważnych, tj. rozpoczęcia oraz ukończenia podstawowej szkoły polskiej i przejścia do szkoły średniej łotewskiej czy rosyjskiej.

Realizując pierwszy projekt pt. Repolonizacja - podwajanie tożsamości. Polsko-totewski eksperyment edukacyjny ${ }^{8}$, zaplanowaliśmy eksplorację środowiska szkoły polskiej w Rydze. Zebraliśmy materiał mający charakter zapisów jakościowych, reprezentowana jest też wiedza o charakterze danych ilościowych. Utworzyliśmy bazę danych zawierającą informacje uzyskane w grupie 144 uczniów oraz ich 72 rodziców w chwili, kiedy dzieci rozpoczynały edukację w szkole polskiej. Towarzysząc dzieciom w życiu codziennym, obserwowaliśmy ich funkcjonowanie w szkole (badając poziom dojrzałości szkolnej, poziom opanowania wiedzy, nabywania kompetencji w zakresie języka), zachowanie w grupie rówieśniczej, a podczas pobytu na wakacjach także relacje z rodzicami. Główne dane zebraliśmy, stosując technikę pogłębionego wywiadu z dziećmi, przeprowadziliśmy także rozmowy z rodzicami badanych według schematu przygotowanego dla uczniów (rodzice otrzymali podobny zestaw pytań, jaki usłyszały dzieci).

Dzięki tym informacjom pochodzącym z różnych źródeł (od dzieci, rodziców, nauczycieli, z dokumentów szkolnych) można było uzupełnić wiedzę o każdym uczniu. Podstawową techniką zbierania danych był pogłębiony wywiad. Kwestionariusz zawierał zestaw pytań dotyczących ich doświadczeń przeszłych, dnia dzisiejszego i wizji przyszłości. To były informacje o możliwościach, jakie posiadali w momencie rozpoczynania nauki w polskiej szkole, oczekiwaniach wobec placówki i nadziejach na przyszłość. Opowiadali o sobie, o wzajemnych relacjach z osobami z bliższego i dalszego otoczenia, charakteryzowali siebie i innych, mówili o środowisku najbliższym i świecie dalekim,

8 W latach 1992-2002 zrealizowano dwa autorskie projekty badawcze (granty KBN). Kierownikiem obydwu była M. M. Urlińska. 
sprawach lokalnych i tych o zasięgu globalnym. Wywiad poparty był obserwacją uczestniczącą, a towarzyszenie uczniom w codziennym życiu szkoły umożliwiało nam bieżącą weryfikację uzyskiwanych od dzieci i rodziców danych.

Po kilku latach powróciliśmy do respondentów, badając absolwentów czterech najstarszych roczników 9-letniej szkoły. Dzięki temu, że przeprowadziliśmy pomiary w dwóch różnych okresach życia uczniów, eksploracja miała charakter badań podłużnych. Powtórzono pomiary na osobach tej samej próbki. Dzięki tej procedurze dzisiaj możemy się wypowiadać o kierunku i zakresie zmian w podmiotach badanych, a także - wiedząc, co wydarzyło się w okresie pomiędzy pomiarami - wnioskować o wpływie owych zdarzeń na konkretne jednostki. Badanie tego typu pozwala śledzić rozwój tychże faktów i analizować je w odniesieniu do zmian dokonujących się pod ich wpływem w uczniach. Badano więc nie takie same, lecz te same podmioty, mierzono cechy w kilkuletnich odstępach czasowych, dzięki temu można było śledzić przepływ tych samych cech między stanem wyjściowym i końcowym.

Decydując się na pomiar dynamiczny panelowy, chcieliśmy uzyskać informacje dotyczące nie tylko trendów występujących w całej populacji, lecz stworzyć sytuację, w której mogliśmy wykreślać indywidualne profile zmiennych. Uzyskaliśmy dzięki temu dynamikę cech obserwowanych i opisywanych świadczącą o tym, jaki jest realny i idealny obraz świata oraz siebie w tym świecie, stereotyp „Innego” w grupie badanych przez nas młodych ludzi (to wszystko w powiązaniu z ich pochodzeniem narodowym). Efektem tego zabiegu było zebranie materiału koniecznego do porównania rozwoju pojedynczych jednostek. Pytania w drugim pomiarze były identyczne jak przed laty, zadaliśmy je tym razem grupie $\mathbf{4 5}$ młodych ludzi kończących szkołę podstawową i ich 17 rodzicom (z pierwszych czterech roczników opuszczających szkołę). Jednak tym razem wywiad pogłębiony zawierał dodatkowo pytania o ocenę lat spędzonych w polskiej szkole, o jej wpływ na jakość życia uczniów oraz określenie ich własnej perspektywy na przyszłość, o subiektywny odbiór sytuacji wewnętrznej (na Łotwie) i zewnętrznej (w Europie). Ważny stał się także przekaz międzypokoleniowy. Zestawienie informacji uzyskanych od dzieci z tymi przekazanymi przez ich rodziców dawało obraz wpływu socjalizacyjnego domu rodzinnego.

Dzięki tak zaprojektowanym badaniom staliśmy się świadkami przekraczania przez dzieci pierwszego progu selekcyjnego. Interesowały nas między innymi strategie obierane przez uczniów stających przed kolejnym wyborem tym razem szkoły średniej. Oczywiste, że wyboru szkoły podstawowej dokonali 
dorośli. Badaczy interesowała odpowiedź na pytanie, czy z decyzji tej dzieci były do końca szkoły podstawowej zadowolone. Z czasem pojawiła się w młodych ludziach świadomość tego, jak powinno wyglądać ich przyszłe życie. Plany swoje część z nich wiązało z Łotwą, niektórzy pragnęli wyjechać do Polski. W tej sytuacji widzieli w kształceniu bilingwalnym, dwukulturowym szansę dla siebie. Dzięki szkole mieli jakiś wybór, a sprzyjało temu zwielokrotnienie ich kompetencji kulturowych. Drugi pomiar wykonano, gdy kończyli edukację w szkole polskiej, dokonywali wyboru kierunku studiów.

Niniejszy projekt badawczy stanowi kontynuację poprzednich eksploracji, tym razem uwaga badaczy skupiona jest na absolwentach szkoły (pierwsze cztery roczniki), dzisiaj młodych trzydziestolatkach, którzy pozostali na Łotwie lub zamieszkali w innych krajach. Problem główny projektowanych badań zawiera się w pytaniach: Jaka jest jakość życia i poczucie osobistego sukcesu młodych absolwentów szkoły polskiej w Rydze i w jaki sposób są one różnicowane cechami usytuowania socjodemograficznego, obecną sytuacją życiową i zawodową, uwarunkowane kontekstem społeczno-kulturowym, w którym funkcjonują jako ludzie dorośli? Proponujemy ujęcie jakości życia i osiągniętego statusu społecznego absolwentów w formie przedstawienia trajektorii ich życia. Jest to inspirowane z jednej strony teorią chaosu w jej warstwie filozoficznej i nośną metafora „efektu motyla”. Jest to anegdotyczne przedstawienie chaosu deterministycznego, kiedy jedna decyzja (wybór szkoły polskiej) może wpłynąć na całe życie i zaważyć na jakość życia w dorosłości ${ }^{9}$. Z drugiej zaś strony istnieje konieczność wyboru koncepcji teoretycznych dotyczących kapitału społecznego, jakości życia czy poczucia osiągnięcia indywidualnego sukcesu.

Jakość życia można rozumieć wielorako. W pierwszej grupie definicji pojęcie utożsamiane jest z jakością świata i człowieka, z odpowiedzialnością za własny los, za wszelkiego rodzaju działania społeczne, kulturalne i pracę zawodową. W takim rozumieniu na jakość życia składają się: bogactwo przeżyć, poziom świadomości i aktywności, twórczość i współuczestnictwo w życiu społecznym. Jakość życia wynika też z uzdolnień do kumulowania przeżyć: im większa umiejętność i możliwość przeobrażania przeżyć w doświadczenia życiowe, tym wyższa jakość życia ${ }^{10}$. W drugiej grupie definicyj-

9 M. Grochalska: Teoria chaosu. Nowy paradygmat socjologii? W: J. Michalski (red.): Sapientia et adiumentum. W trosce o rozwój innych. Olsztyn 2006, UWM.

10 S. Kowalik: Jakość życia pacjentów w procesie leczenia. W: B. Waligóra (red.): Elementy psychologii klinicznej. T. IV. Poznań 1995, UAM, s. 76. 
nej jakość życia rozpatrywana jest pod kątem realizowanych przez człowieka zadań: zarówno rozwojowych, jak i życiowych. Zadania rozwojowe związane są z postępem i umiejętnością przyjęcia je za własne oraz wypełnianiem ról i oczekiwań społecznych. Z kolei zadania życiowe, na które składają się bieg życia i ogrom materiałów poznawczych, przyczyniających się do wykorzystania zdobywanych informacji, mogą stać się przyczyną wielu rozmaitych kryzysów zwiększających doświadczenia jakości życia ${ }^{11}$.

Trzecia grupa definicji utożsamia jakość życia ze stopniem zaspokojenia potrzeb jednostki. Obejmuje potrzeby, które jednostka uważa za najistotniejsze dla swojego życia, oraz opinie jednostki na temat poziomu ich zaspakajania. Analiza aktualnych potrzeb może być „próbą opisu świata życia oraz przestrzeni, w której funkcjonują ludzie", rozpatrując to, co obiektywne (mierzalne zewnętrznie) i co subiektywne (stan świadomości zadowolenie) ${ }^{12}$. W określaniu jakości życia bierze się również pod uwagę znaczenie wskaźników subiektywnych i obiektywnych. Miara obiektywna będzie obejmować warunki egzystencji grup społecznych w sensie materialnym czy zdrowotnym, które podlegają kryteriom wartościowania. Natomiast subiektywne kryterium jakości życia odnosić się będzie do indywidualnych kryteriów wartościowania jednostki i obejmować będzie ocenę życia w poszczególnych jego aspektach i doświadczeniach, jak również cechy dyspozycyjne warunkujące jej postawę wobec życia ${ }^{13}$.

W niniejszym projekcie definicja operacyjna jakości życia to indeks złożony z różnych elementów warunkujących zadowolenie z życia jednostek i grup społecznych. Na użytek diagnozy przyjmuję, że na jakość życia składają się: stopień samorealizacji jednostek (mierzony satysfakcją z osiągniętego wykształcenia, osiągniętego statusu zawodowego i społecznego, aktywności własnej, oceną kondycji fizycznej, psychicznej oraz poziomem dochodów i stopniem zaspokojenia potrzeb materialnych i niematerialnych), stopień zadowolenia jednostek ze sposobu funkcjonowania grup społecznych, do których należą (grupy rodzinnej, grupy mniejszościowej, lokalnej grupy zawodowej, lokalnej

11 A. Bańka, R. Derbis (red.): Pomiar i poczucie jakości życia u aktywnych zawodowo oraz bezrobotnych. Poznań - Lublin 1995, Środkowoeuropejskie Centrum Ekonomii Działania Społecznego, s. 19.

12 R. Borowicz: Równość i sprawiedliwość społeczna. Warszawa 1988, PWN, s. 53.

13 J. Czapiński: Psychologiczne teorie szczęści. W: J. Czapiński (red.): Psychologia pozytywna. Nauka o szczęściu, zdrowiu, sile i cnotach człowieka. Warszawa 2004, PWN. 
grupy osiedleńczej, na przykład wspólnoty mieszkaniowej, lokalnej społeczności, na przykład dzielnicy, wsi, miasteczka, społeczeństwa); poziom zadowolenia jednostek ze sposobu funkcjonowania instytucji (władzy lokalnej, instytucji obsługi mieszkańców, w tym w szczególności instytucji kulturalnych i edukacyjnych); poziom zadowolenia jednostek ze standardu cywilizacyjnego miejsca zamieszkania (mierzony stanem infrastruktury, w tym: transportowej, mieszkaniowej, komunikacyjnej, ochrony środowiska i kulturalnej); poziom zadowolenia jednostek z debaty publicznej i standardów demokratycznych w życiu publicznym na płaszczyźnie lokalnej i ogólnospołecznej.

Kolejnym pojęciem kluczowym dla niniejszego projektu jest kategoria sukcesu. W potocznym rozumieniu sukces oznacza triumf w działaniu, pomyślny wynik jakiegoś przedsięwzięcia. Słownik wyrazów obcych traktuje go jako „powodzenie, pomyślność, udanie się, pomyślny skutek czegoś [...] dążymy do sukcesów, ponieważ daje nam to poczucie samorealizacji”" ${ }^{14}$. Takie działanie chroni nas przed stagnacją i rutyną oraz stanowi mobilizację do dalszego rozwoju. Rozumienie pojęcia sukcesu może być dla każdego czymś indywidualnym, wyjątkowym, ale jednocześnie czymś, co w żaden sposób nie może być kojarzone negatywnie. Według niektórych sukces kojarzony może być z udanym życiem rodzinnym, dobrą sytuacją materialną czy zawodową. W związku z tym istotne jest poznanie indywidualnych interpretacji pojęcia, aby na podstawie tego uzyskać dalsze informacje takie jak: poczucie osiągnięcia sukcesu i satysfakcji czy sposoby realizacji celów.

Wśród teorii społecznych obejmujących kategorię jakości życia wykorzystaną w projekcie jest teoria społeczna Pierre'a Bourdieu. Autor stwierdził, że określonej wielkości odziedziczonego kapitału (kulturowego, społecznego) odpowiada wiązka trajektorii mniej więcej równie prawdopodobnych, prowadzących do równoważnych pozycji społecznych. Jest to pole możliwości danego człowieka, przy czym trajektoria najbardziej prawdopodobna dla grupy ludzi wyodrębnionej na podstawie podobnej wielkości określona tu została mianem modalnej ${ }^{15}$. W tym przypadku trajektorię modalną wyznaczać będzie funkcjonowanie w życiu dorosłym absolwentów polskiej placówki. Jednakże niektóre trajektorie indywidualne w tej grupie mogą się znacznie różnić od modalnej za sprawą różnych czynników - większych lub mniejszych wydarzeń społeczno-ekonomiczno-kulturalnych w kraju, jak też

14 Za: I. Majewska-Opiełka: Korepetycje z sukcesu. Poznań 2005, „Rebis”, s. 12.

15 P. Bourdieu: Dystynkcja. Społeczna krytyka władzy sadzenia. Warszawa 2005, „Scholar", s. 143. 
drobnych, codziennych zdarzeń biograficznych. Poczucie subiektywne jakości życia indywidualnego człowieka warunkowany jest zatem jego potencjałem kulturowym i społecznym. Wobec powyższego zdefiniowania wymaga pojęcie kapitału.

Kapitał kulturowy jednostek i grup to całościowy zasób dóbr kulturowych (materialnych i niematerialnych), które są im dostępne. Istnieje on w trzech postaciach: jako kapitat wcielony, czy też zinternalizowany (wiedza tworząca trwałe dyspozycje jednostki, czyli kompetencje, przejawia się $\mathrm{w}$ formie umiejętności odnoszących się do jakiejś dziedziny, w poprawnym użyciu języka, znajomości konwencji, orientacji w świecie społecznym); jako kapitał zobiektywizowany (czyli posiadane przez jednostki i grupy dobra materialne czy dziedzictwo kulturowe: obrazy, książki, instrumenty, maszyny, architektura itd.); jako kapitał zinstytucjonalizowany (ujawnia się poprzez uznanie społeczne, nadane przez władzę np. państwową tytuły, dyplomy, zwycięstwa w konkursach). Nabycie kapitału kulturowego wymaga osobistej pracy jednostki i jej otoczenia społecznego (wzorce, kontrola, trening), czasu i środków materialnych.

Szczególnie ważny dla projektu jest jednak kapitał społeczny, czyli sieć relacji społecznych, w jakich istnieją jednostki i grupy. Sieć ta może mieć charakter zamykający (wtedy mówi się o kapitale wiążącym) oraz otwarty (wtedy używa się określenia „kapitał pomostowy”). Oba podtypy mogą sprzyjać rozwojowi jednostek i społeczności, ale moga go też utrudniać. Zależy to od specyfiki konkretnych więzi między ludźmi. Kapitał społeczny opisywany jest najczęściej jako całokształt relacji, kontaktów, więzi - w tym przyjaźni i zobowiązań, których rozległość i intensywność pozwalają jednostce działać w dostępnej jej przestrzeni społecznej - a także jako przynależność do różnych grup społecznych i trwała sieć relacji, w które uwikłana jest jednostka ludzka. Kapitał społeczny według Colemana to umiejętność współpracy, a zarazem "naturalny zasób” tkwiący w relacjach społecznych ${ }^{16}$. Wyraża się on w trzech formach: zaufaniu do siebie samego i siebie nawzajem; normach podzielanych przez daną grupę; więziach społecznych łączących członków grupy. Kapitał społeczny jest bezpośrednio powiązany z kapitałem kulturowym i ekonomicznym, ponieważ wzmacniają one nawzajem swoją efektywność. Związane z tymi kapitałami „strategie inwestycji społecznych”, które jednostka stosuje świadomie lub nieświadomie, umożliwiają jej wyciąganie

16 J. S. Coleman: Foundations of Social Theory. Cambridge 1990, Harvard University Press. 
korzyści materialnych i symbolicznych z kontaktów z innymi ludźmi oraz prawomocną wymianę treści kulturowych i wykluczanie relacji uznawanych za nieprawomocne.

W obrębie obydwu kapitałów można przyjrzeć się wszystkim sieciom wytworzonych, dziedziczonych, nabytych wartości pozwalającym na transgresyjne ich przenikanie sprzyjające rozwojowi i podwajaniu tożsamości. Uspójnienie dotyczyłoby zatem w tym przypadku wzrostu spójności społecznej, polegającej na zmniejszaniu zróżnicowań w wykorzystaniu kapitału ludzkiego pomiędzy poszczególnymi obszarami UE i Łotwy oraz spójności terytorialnej, polegającej na eliminowaniu barier dostępności do regionów centralnych UE rozumianej jako Wspólnoty. Zasygnalizowany tutaj wzór czerpania wzorców z ośrodków centralnych, ale i regionów wybranych w projekcie (kraje osiedlenia absolwentów szkoły polskiej w Rydze), praktykowany w obszarze edukacji, wyznaczać może nowe definiowanie pojęcia rozwoju w odniesieniu do potencjału i dynamiki przenikania wspomnianych wyżej kapitałów kulturowych i społecznych, w których osadza się kategorię tożsamości. Istotną przeszkodę rozwojową, sygnalizowaną w literaturze, stanowić mogą splątane korzenie pochodzenia mieszkańców tych regionów, którzy przede wszystkim na skutek powojennych migracji znaleźli się na terenach obcych własnej tradycji i żyją tutaj razem z innymi „obcymi”, nie zawsze tworząc harmonijną wspólnotę. Ów brak społecznej integracji odbija się na jakości edukacji ${ }^{17}$.

Kategoria tożsamości, a tym bardziej jej podwajania, ma charakter temporalny, ponadontologiczny, procesualny, rozwojowy, co pozostaje w związkach z horyzontem rozwoju pogranicza kultur jako względnie wyodrębnionych terenów życia ludzi ukierunkowanych przez odpowiednie strategie. Pod hasłem „horyzontu pogranicza kultur” rozumieć należy jakość jego antycypowanej, a nawet planowanej przyszłości, nawiązującej do specyfiki jego kultury. Związek owej przyszłości z jakością edukacji oznacza, że wyobrażanym kierunkom i perspektywom rozwoju danego terytorium przyporządkowuje się długofalowe zamierzenia edukacyjne, traktowane wówczas instrumentalnie jako formy aktywności wspierające uzyskiwanie pożądanych stanów danego regionu. Faktycznie realizowane edukacyjne inicjatywy mogą wpisywać się w tę logikę, a dzieje się tak wtedy, kiedy horyzonty rozwoju - w tym toż-

17 Z. Kawczyńska-Butrym (red.): Młodzież z województwa warmińsko-mazurskiego. Zagrożenia, szanse, plany życiowe. Olsztyn 2006, Olsztyńska Szkoła Wyższa im. Józefa Rusieckiego. 
samościowego - są odbierane przez ludzi jako bliskie ich potrzebom i wspólnotowe. Problem stał się niezwykle aktualny wraz z wstąpieniem nie tylko Polski, ale i Łotwy w struktury UE. Przejście do kapitalizmu, zglobalizowanej gospodarki jest bowiem jednocześnie przykładem translacji istniejących światów, a ta wiąże się ściśle z teorią i polityką spójności Unii Europejskiej ${ }^{18}$. Jak wiadomo, jednym z jej celów jest konwergencja kapitałów państw członkowskich w zakresie kapitałów rzeczowych, kulturowych i ludzkich.

W rozwiązywaniu tej kwestii służyć może/będzie w projekcie teza Woydyło-Osiatyńskiej zakładająca, że dla rozwoju potrzebne jest „indywidualne, osobiste dostrzeżenie własnych skrzydeł, nie tylko korzeni”. Wieloletnie skierowanie wstecz i skupianie się na sprawach korzeni, bolesne, lecz zarazem bezskuteczne ich rozplątywanie może pochłaniać całą energię ludzi i wtedy powstaje niebezpieczeństwo własnego zaplątywania się w rozplątywanie korzeni, co pochłania zasoby i powoduje, że mało sił poświęca się na tworzenie skrzydeł rozwoju, niezbędnych dla budowania pomyślnej przyszłości ${ }^{19}$. Warto więc rozważać proporcje energii wkładanej w „kwestię korzeni” i w „kwestię skrzydeł" i racjonalizować wkłady tak, aby nie tracić z oczu sprawy perspektyw wspólnych w formule „horyzontów pogranicza kultur”20. Osadzenie projektu w perspektywie polityki spójności ${ }^{21}$ pozwala na podejmowanie działań edukacyjnych sprzyjających rozpoznawaniu dynamiki rozwoju tożsamości i kultury czasu dzisiejszego oraz kierowaniu uwagi ludzi na przyszłość, operujące intensywnymi bodźcami rozwojowymi, służące wzbogacaniu operowania przez ludzi kapitałem symbolicznym, poszerzania horyzontów grup społecznych i jednostek, dostrzegające lokalność, ale zarazem wychodzące poza to, co najbliższe, $\mathrm{z}$ nastawieniem na uzupełnianie wszelkich kulturowych i społecznych braków. W obrębie obydwu kapitałów interesuje nas przede wszystkim sieć wytworzonych, dziedziczonych, nabytych wartości.

18 Por.: D. Chakrabarty: Prowincjonalizacja Europy: myśl postkolonialna i różnica historyczna. Poznań 2011, Wydawnictwo Poznańskie; M. Morawski: Konfiguracje globalne - struktury, agencje, instytucje. Warszawa 2010, PWN.

19 B. Fatyga: Kultura pod chmurnym niebem. Dynamiczna diagnoza stanu kultury województwa Warmińsko-Mazurskiego. Raport i rekomendacje praktyczne. Warszawa - Olsztyn 2012, Urząd Marszałkowski Województwa Warmińsko-Mazurskiego, s. 62.

20 P. Churski: Czynniki rozwoju regionalnego w świetle koncepcji teoretycznych. chur@amu.edu.pl.

${ }^{21}$ K. Gawlikowska-Hueckel: Procesy rozwoju regionalnego w Unii Europejskiej. Konwergencja czy polaryzacja? Gdańsk 2003, UG. 
Celem podjęcia niniejszych badań jest zatem pokazanie, jaka jest jakość życia młodych absolwentów szkoły polskiej w Rydze, którzy w przeszłości dokonali wyborów życiowych (własnych ścieżek edukacyjnych, wyboru zawodu, osiągnęli pewien status społeczny, funkcjonują w określonych rolach społecznych). W ramach prowadzonych analiz uwzględnione zostaną uwarunkowania kształtowania się kapitału kulturowego i społecznego, zostanie opisana sytuacja życiowa badanych osób (zdrowotna, podmiotowo-psychologiczna, społeczna, zawodowa i ekonomiczna) oraz poczucie sukcesu z osiągnięć indywidualnych badanych. Usytuowanie w niniejszym projekcie problemu badawczego w warunkach różnych krajów, w których znaleźli się absolwenci (mamy tutaj do czynienia ze wzmożoną migracją młodych w poszukiwaniu miejsca dla siebie, bowiem $40 \%$ z pierwszych czterech roczników wyemigrowało poza granice Łotwy), nabiera szczególnego znaczenia ze względu na cechy dystynktywne wybranych regionów, do których zalicza się zróżnicowaną skalę problemów społecznych, ograniczony styl i treść komunikacji społecznej, różne postrzeganie zadań i szans rozwojowych mieszkańców.

Przedmiotem zainteresowania diagnozy ukierunkowanej na rozwiązanie problemu badawczego są w niniejszym projekcie transgresyjne trajektorie życia młodych absolwentów szkoły polskiej prowadzące do uniknięcia społecznego wykluczenia z powodu przynależenia do mniejszości polskiej na Łotwie w kraju wielokulturowym doświadczonym sowiecką indoktrynacją. Poprzez edukację w placówce zorganizowanej przez pokolenie zstępujące (dziadkowie pamiętający czasy przedwojenne, kiedy to mogli funkcjonować w „świecie polskim”, uczęszczać do szkół polskich) możliwe stało się skrystalizowanie własnej tożsamości indywidualnej i grupowej, wykształcenie jednostki zdolnej do przekraczania siebie. Natomiast poprzez dołożenie pierwiastka łotewskiego (program szkoły wzbogacony o naukę języka, kultury, tradycji łotewskiej) możliwe stało się wyjście z kręgu własnej grupy narodowej (by nie utrwalać i dziedziczyć jej losu, w tym także kotwiczenia w izolowanym świecie, zamkniętym tylko w tradycji polskiej). To zintegrowanie możliwe jest dzięki zwielokrotnieniu kompetencji kulturowych umożliwiających funkcjonowanie w świecie zróżnicowanym i niejednoznacznym. Poprzez pokazanie losów absolwentów, w tym także sposobów radzenia sobie z problemami dnia codziennego młodych trzydziestolatków, ich walki o zdobycie pozycji i satysfakcjonującego ich statusu społecznego, możliwe będzie wyróżnienie obiektywnych wskaźników jakości życia osób badanych, jak też ich subiektywnego odczuwania dobrostanu. 
Poprzez analizę losów absolwentów szkoły polskiej na Lotwie możliwe będzie poznanie subiektywnej interpretacji pojęć „jakość życia” i „sukces” oraz wskazanie determinantów i wyznaczników ich osiągnięcia. Zamiarem naszym jest również zdobycie wiedzy na temat poczucia osiągnięcia dobrostanu, sukcesu, spełnienia, samorealizacji i satysfakcji z przebiegu dotychczasowego życia. Punktem wyjścia w naszych działaniach będzie analiza dotychczasowych badań nad jednostkami uczęszczającymi do polskiej szkoły na Łotwie. Z przeprowadzonych już badań zaczerpniemy wiedzę na temat funkcjonowania środowiska rodzinnego obecnych absolwentów oraz uzyskamy informacje na temat ich edukacji. Aby poznać determinanty sukcesu, czynniki wpływające na jego osiągnięcie, należy dokonać analizy dotychczasowych badań nad uczniami polskiej szkoły na Łotwie.

Na rozwój, edukację i osiągnięcia dziecka wpływa zarówno środowisko rodzinne, jak i szkolne. Zatem znaczenie mogą mieć wychowanie, inkulturacja, akulturacja, socjalizacja i edukacja. Według Kawuli podstawą analizy funkcjonowania rodziny oraz poziomu jej działalności wychowawczej są trzy grupy czynników, a mianowicie: czynniki ekonomiczno-społeczne, czynniki kulturowe oraz czynniki psychopedagogiczne ${ }^{22}$. Na grupę pierwszą składają się następujące elementy: struktura rodziny i jej wielkość, źródła utrzymania, sprawowanie opieki materialnej nad dziećmi, podział pracy i ról w rodzinie. Do grupy czynników kulturowych zalicza się wykształcenie rodziców, dokształcanie się i zdobywanie przez nich kwalifikacji, sposoby wykorzystania czasu wolnego przez poszczególnych członków rodziny, stosunek rodziców do nauki szkolnej dzieci i ich przyszłego zawodu, ich stosunek do tradycji i nowości oraz wyznawane przez rodziców normy i wzorce wychowania. Czynniki psychopedagogiczne dotyczą atmosfery panującej w rodzinie, relacji między poszczególnymi jej członkami, nieprawidłowości w interakcjach wewnątrzrodzinnych, charakteru stosunków między rodzicami, a także pomiędzy rodzicami a dziećmi, sposobu kontroli rodziców nad dziećmi oraz stosowanych metod i środków wychowawczych. To właśnie te czynniki będą podstawą dokonanej przez nas analizy środowiska rodzinnego absolwentów. Poznając osobiste poczucie osiągnięcia sukcesu przez badane jednostki, odwołamy się do zagadnienia miary sukcesu. Jedno z postawionych przez nas pytań jest następujące: po czym badane jednostki mogą poznać, że osiągnęły sukces? Miarą może być zarówno wielkość tego, co udało się osiągnąć, jak

22 S. Kawula, J. Brągiel, A. W. Janke: Pedagogika rodziny. Toruń 1988, Wydawnictwo Adam Marszałek, s. 75. 
również ilość i wielkość przeszkód czy ograniczeń, jakie należało pokonać w realizacji stawianych sobie celów. Zatem wskaźnikiem sukcesu może być dokonany postęp przy posiadanych możliwościach i umiejętnościach jednostki (funkcja emancypacyjna).

W próbie badawczej mamy 30 absolwentów (z 45 osób w przeszłości podwójnie badanych), po 10 z każdej z trzech wyróżnionych grup (w jednej są ci, którzy wyemigrowali na Zachód, w drugiej absolwenci osiedli w Polsce, a w trzeciej ci, którzy pozostali na Łotwie). Dobór próby ma charakter celowy, bowiem jest podyktowany chęcią zbadania, jak różna może być jakość życia absolwentów jednej szkoły, dokonujących własnych wyborów po zdaniu matury, doświadczonych odmiennymi problemami (zasobność materialna rodziny, trudna sytuacja związana z bezrobociem członków rodzin, decyzje migracyjne), jakie są uwarunkowania stylu życia, jakie wartości, jak postrzegają przeszłość swoją i jak widzą przyszłość. Badamy ich dobrostan, a w nim poczucie osiągnięcia osobistego sukcesu i ocenę, jaką rolę w tym odczuciu odegrała szkoła polska.

Podejmowane przez nas działania będą zmierzały do wyprowadzenia wniosków adekwatnych do założonego celu badania, w konsekwencji poprzez ukazanie losów absolwentów szkoły polskiej w Rydze wskazania na uwarunkowania i wytworzony kapitał społeczny podnoszący jakość ich życia oraz dający poczucie osobistego sukcesu. Szczegółowe, obiektywne i wieloaspektowe podejście do problemu i rozpatrzenie każdego z badanych przypadków pozwoli na uniknięcie generalizacji zjawiska. Sytuacja każdego z przypadków różni się bowiem pod wpływem indywidualnych doświadczeń. Zatem punktem wyjścia wszelkich rozważań będzie dokładne poznanie wyników dotychczasowych naszych badań wybranych przypadków.

\section{Bibliografia}

Bańka A., Derbis R. (red.): Pomiar i poczucie jakości życia u aktywnych zawodowo oraz bezrobotnych. Poznań - Lublin 1995, Środkowoeuropejskie Centrum Ekonomii Działania Społecznego.

Borowicz R.: Równość i sprawiedliwość społeczna. Warszawa 1988, PWN.

Bourdieu P.: Dystynkcja. Społeczna krytyka władzy sqdzenia. Warszawa 2005, "Scholar". 
Chakrabarty D.: Prowincjonalizacja Europy: myśl postkolonialna i różnica historyczna. Poznań 2011, Wydawnictwo Poznańskie.

Churski P.: Czynniki rozwoju regionalnego w świetle koncepcji teoretycznych. chur@amu.edu.pl

Coleman J. S.: Foundations of Social Theory. Cambridge 1990, Harvard University Press.

Czapiński J.: Psychologiczne teorie szczęści. W: J. Czapiński (red.): Psychologia pozytywna. Nauka o szczęściu, zdrowiu, sile i cnotach człowieka. Warszawa 2004, PWN.

Fatyga B.: Kultura pod chmurnym niebem. Dynamiczna diagnoza stanu kultury województwa Warmińsko-Mazurskiego. Raport i rekomendacje praktyczne. Warszawa - Olsztyn 2012, Urząd Marszałkowski Województwa Warmińsko-Mazurskiego.

Gawlikowska-Hueckel K.: Procesy rozwoju regionalnego w Unii Europejskiej. Konwergencja czy polaryzacja? Gdańsk 2003, UG.

Grochalska M.: Teoria chaosu. Nowy paradygmat socjologii? W: Michalski J. (red.): Sapientia et adiumentum. W trosce o rozwój innych. Olsztyn 2006, UWM.

Kawczyńska-Butrym Z. (red.): Młodzież z województwa warmińsko-mazurskiego. Zagrożenia, szanse, plany życiowe. Olsztyn 2006, Olsztyńska Szkoła Wyższa im. Józefa Rusieckiego.

Kawula S., Brągiel J., Janke A. W.: Pedagogika rodziny. Torun 1988, Wydawnictwo Adam Marszałek.

Kowalik S.: Jakość życia pacjentów w procesie leczenia. W: B. Waligóra (red.): Elementy psychologii klinicznej. T. IV. Poznań 1995, UAM.

Lewowicki T., Ogrodzka-Mazur E. (red.): W poszukiwaniu teorii przydatnych w badaniach międzykulturowych. Cieszyn 2001, UŚ - Filia w Cieszynie.

Majewska-Opiełka I.: Korepetycje z sukcesu. Poznań 2005, „Rebis”.

Mead M.: Kultura i tożsamość. Warszawa 1978, PWN.

Morawski M.: Konfiguracje globalne - struktury, agencje, instytucje. Warszawa 2010, PWN.

Okoń W:: Nowy słownik pedagogiczny. Warszawa 2004, „Żak”.

Palka S.: Metodologia badania. Praktyka pedagogiczna. Gdańsk 2006, GWP. Pilch T., Bauman T.: Zasady badań pedagogicznych. Strategie ilościowe i jakościowe. Warszawa 2001, „Żak”.

Pilch T., Smolińska-Theiss B., (red): Pedagogika społeczna. „Studia Pedagogiczne" 1984, T. XLVI.

Schulz R.: Szkoła - instytucja - system - rozwój. Toruń 1992, „Edytor”. 
Trempała E.: Instytucje i placówki wychowania równoległego. W: T. Pilch, B. Smolińska-Theiss (red.): Pedagogika społeczna - poszukiwania i rozstrzygnięcia. Wrocław - Warszawa 1984, Zakład Narodowy im. Ossolińskich.

Tyszkowa M.: Relacje dorastających wnuków z dziadkami i babciami. „Problemy Rodziny" 1992, nr 1.

Urlińska M. M.: Szkoła polska na obczyźnie wobec dylematów tożsamościowych. Torun 2007, UMK.

\section{Quality of life and feeling of success among the graduates of the Polish school in Latvia - a collective case study}

\section{Summary}

For 25 years, the scientific environment of Torun has observed (taking active part in this process in the beginning) the activities of Poles in Latvia which aim at reconstruction of the school for the Polish minority. Conducting longitudinal studies allows for grasping the dynamics in the process of transmission of Polish culture, tradition and language. It can also help to indicate the role of school learners, teachers and parents and their significance for the feeling of national identity of young Poles born and living in Latvia, who make use of the chance to be educated both in the Polish and Latvian language. The learners were accompanied by researchers during their school education, including such significant moments as the start and graduation from the Polish primary school and transition into Latvian or Russian secondary school. The presented research project is a continuation of previous explorations - this time the graduates (the first four years), currently young people at their thirties, are focused on. The main problem in the planned research is comprised in the question: What is the quality of life and feeling of personal success of young graduates of the Polish school in Riga and how are they differentiated by socio-demographic situation, current life and career situation as well as determined by the socio-cultural context in which the graduates live as adults? What the author suggests is to show the graduates' quality of life and their achieved social status by presenting the trajectory of their life.

Key words: feeling of identity, cultural and social capital, quality of life, feeling of success, Polish school system abroad, trajectories of life 